\title{
Hastane Hizmetlerinin İyileştirilmesinde Kalite Fonksiyonu Göçerimi (KFG) Yönteminin Kullanılması ve Nesnelerin İnterneti Teknolojisiyle Model Önerisi
}

\author{
Muhsine Nur Naralan Nursaçan ${ }^{1 *}$, Tahsin Çetinyokuş ${ }^{2}$ \\ 1* Gazi Üniversitesi, Bilişim Enstitüdü, Yönetim Bilişim Sistemleri Bölümü, Ankara, Türkiye, (ORCID: 0000-0003-2991-137X), mhsnnrnrln@gmail.com \\ ${ }^{2}$ Gazi Üniversitesi, Mühendislik Fakültesi, Endüstri Mühendisliği Bölümü, Ankara, Türkiye (ORCID: 0000-0002-9963-5174), tahsinc@gazi.edu.tr
}

(Ilk Geliş Tarihi 3 Temmuz 2020 ve Kabul Tarihi 10 Ekim 2020)

(DOI: 10.31590/ejosat.763127)

ATIF/REFERENCE: Naralan Nursaçan, M. N. \& Çetinyokuş, T. (2020). Hastane Hizmetlerinin İyileştirilmesinde Kalite Fonksiyonu Göçerimi (KFG) Yönteminin Kullanılması ve Nesnelerin İnterneti Teknolojisiyle Model Önerisi. Avrupa Bilim ve Teknoloji Dergisi, (20), 181-195.

$\ddot{\mathbf{O} z}$

Teknolojik gelişmeler yaşam kalitemizi arttırmak ve hayatımızı kolaylaştırmak amacı taşımaktadır. Sağlık Hizmetleri’nin sunulduğu hastanelerin daha iyi hizmetler sunması ve insanların yaşam kalitesine doğrudan etki etmesi sebebi ile gelişen teknolojilere adapte olması gerekmektedir. Bu çalışmanın amacı sistematik bir yol izlenebilmesi için Kalite Fonksiyonu Göçerimi yönetimi kullanılarak, sağlık sektörüne etkisi ortaya konulan Nesnelerin İnterneti (IoT)'nin hastanelerde sunulan sağllk hizmetlerinin iyileştirilmesinde bir model önerisi sunmaktır. Müşteri ihtiyaçları Servqual ölçeği yardımı ile uzman ekip danışmanlığı tarafından belirlenmiş, bu ihtiyaçlara Nesnelerin İnterneti kapsamında önerilebilecek teknik gereksinimler sunulmuş ve Kalite Fonksiyonu Göçerimi yöntemi uygulanmıştır. Çalışmada ortaya çıkan Kalite Evi incelendiğinde en yüksek önem derecesine sahip teknik gereksinimin ;"Kablosuz Vücut Algılayıcıları ile sağlık birimlerine uyarı sistemi oluşturulması" olduğu belirlenmiş bunu sırası ile "İnternet ve mobil uygulamalar üzerinden sağlık danışmanlığı" ve "Kablosuz erişim noktası sayısının arttırılması" izlemiş̧tir.

\section{Using Quality Function Deployment (QFD) Method in Improving Hospital Services and Model Proposal in Internet of Things Technology}

\begin{abstract}
Technological developments aim to make our lives easier and to improve our quality of life. The hospitals in which the Health Services are provided, need to adapt to the developing technologies to provide better services as they have a direct impact on the quality of life of the people. The aim of this study is to propose a model for the use of the Internet of Things (IoT), the effect of which has been demonstrated on the health sector, in the improvement of the health services provided in hospitals by using Quality Function Deployment management in order to follow a systematic way. Customer needs are determined by expert team consultancy with the help of Servqual scale, technical requirements are presented that can be suggested within the scope of the Internet of Things and the Quality Function Deployment method is applied. When the Quality House emerging in the study is analyzed, it is seen that the technical requirements with the highest importance is "Establishing a warning system for health units with Wireless Body Sensors", followed by "Health counseling over the Internet and mobile applications" and "Increasing the number of wireless access points", respectively.
\end{abstract}

Keywords: Internet of Things, Quality Function Deployment, Health Services, Servqual scale.

\footnotetext{
* Sorumlu Yazar: mhsnnrnrln@gmail.com
} 


\section{Giriş}

Teknolojik gelişmeler ile birlikte insan hayatında birçok değişim olmuştur. Bu değişimler ve gelişmeler yaşam kalitesini arttırma amacı taşımaktadır. Birçok alanda yapılan çalışmaların yanı sıra sağlık alanında yapılan çalışmalar yaşam kalitesine doğrudan etki etmektedir. Günümüzde sağlık, sadece sosyolojik bir olgu olarak değil ekonomik ve politik bir olgu olarak da karşımıza çıkmaktadır. Ülkelerin refah seviyelerine bakılırken sağlık sisteminin ülke nüfusu için gerekli tüm sağlık ihtiyacını karşılayacak nitelikte olması dikkate alınmalıdır. Sağlık hizmetlerinin kalitesi, insanların yaşam kalitesinin artmasına aynı zamanda ülkenin de refah seviyesine ve gelişmişlik düzeyine etki etmektedir. Sağlık Hizmetleri'ne istenilen zamanda, istenilen yerden erişim imkânı sunulması ile birlikte çalışmalar uzman sistemlere doğru yönelmiştir. İncelenen makalelerde sağllk hizmetlerinin gerçek zamanlı veriye ve hassas analizlere ihtiyaç duyulan en önemli sektör olduğu görülmektedir.

Küreselleşmenin etkilerinin kaçınılmaz olduğu ve teknolojinin ortaya çıkardığı problemleri çözmek üzere başka teknolojilerin geliştirildiği çağımızda, gelişmiş hizmetler sunmak üzere bilgi ağlarına fiziksel nesnelerin entegre edilmesi ile birlikte Nesnelerin İnterneti ortaya çıkmıştır. İnternetin kolay ulaşılabilir olması Nesnelerin İnternet'inin gelişmesine büyük katkı sağlamaktadır. Yapılan literatür taramasında Nesnelerin İnterneti (IoT)'nin Sağlık Hizmetlerinde ne gibi değişimlere sebep olduğu görülmektedir. Nesnelerin İnterneti (IoT) tabanında Kablosuz Vücut Alan Ağları ve Sensörlerin oluşturduğu bir altyapı ile birlikte toplanan verilerin Bulut tabanlı depolama ve hesaplama ara katmanı sayesinde son kullanıcılara; doktorlara, hemşirelere, hastalara istenilen bilgilerin sağlanması ile sağlık hizmetleri her zaman ve her yerde verilmeye başlanmıştır.

Literatüre bakıldığında sağlık kuruluşlarının geliştirilmesinde Kalite Fonksiyonu Göçerimi (KFG) yönteminin kullanıldığı görülmektedir. Akdağ ve arkadaşlarının yaptıkları çalışmada, müşteri ihtiyaç ve beklentilerini özel bir sağlık hizmeti ortamında kalite özelliklerine dönüştürmek için kalite fonksiyon göçerimi yönteminin nasıl kullanıldığını bir vaka çalışması ile kalite iyileştirmesi için mevcut bir Servqual ve KFG entegrasyonu yaklaşımının nasıl uygulanabileceği gösterilmiştir (CamgözAkdağ, Tarım, Lonial, \& Yatkın, 2013). Benzer bir çalışma Aktepe ve arkadaşları tarafından yapılmış ancak Servqual yönteminin boyutları ana kriterler ve bu boyutlarla ölçülen değişkenler alt kriterler olarak düşünülerek ağırlıklandırma Bulanık Analitik Hiyerarşi Prosesi (BAHP) ile gerçekleştirilmiştir (Aktepe, ve diğerleri, 2011). 2012 yılında Çiğdem Değer tarafından yapılan yüksek lisans tez çalışmasında Kalite Fonksiyonu Göçerimi yöntemi Servqual ve Kano modelleri ile bütünleştirilerek bir model elde edilmiştir. Tez çalışmasında Servqual Modeli ile işletmenin beklenen ve algılanan hizmet puanları hesaplanmış, Kano Modeli çalışmaya dahil edilerek müşteri isteklerinin hangi sıra ile karşılanması gerektiği bulunmuş, daha sonrada bu veriler kullanılarak Kalite Fonksiyon Yayılımı yöntemi ile Kalite Evine yerleştirilmiştir (Değer, 2012). Al Memari'nin yapmış olduğu tez çalışmasında toplam kalite sağlık modeli geliştirmek için bir teknik olarak Kalite Fonksiyon Göçerimi (KFG) seçilme nedenleri üzerinde durulmaktadır. Hastane tabanlı bir vaka çalışmasının yardımıyla sağlık hizmetinde KFG kullanılma olasılığını araştırmaktadır. Al Memari çalışmasında sonuçlara dayanarak, sağlık yönetimini toplam kalite gelişimlerinde yönlendirmek için toplam kalite modeli geliştirmiştir (Al Memari, 2016). Bahsedilen çalışmalarda da görüldüğü üzere endüstriyel üretim geliştirme yöntemi olarak ortaya çıkan KFG, sağlık sektörü ve farklı sektörlerde de hizmet kalitesinin arttırılmasında kullanılmaya başlanmıştır. $\mathrm{Bu}$ araştırmalarda müşteri sesinin dinlenmesinde çoğunlukla KFG ile birlikte Servqual ölçeğinin bütünleşik olarak kullanıldığı da görülmektedir.

Nesnelerin İnterneti; çok sayıda farklı ve heterojen uç sistemleri bir araya getirerek, çok sayıda dijital servisin geliştirilmesi için seçilen veri alt kümelerine açık erişim sağlayabilmektedir. Sahip olduğu potansiyel ile gerçek zamanlı veri sağlaması ve nesnelere uzaktan erişim imkânı sağlayabilmesi özellikleri birçok sektörde gelişim sağlamış ve bu sektörleri bir üst seviyeye taşımıştır. Nesnelerin İnternet'inin Sağlık Hizmetleri ile etkileşimi diğer sektörlere kıyasla insan hayatı için daha büyük bir önem arz etmektedir. Sağlık Hizmetlerinin de Nesnelerin İnternet'ini kullanarak gelişmesi kaçınılmazdır. Literatür incelendiğinde birçok çalışmanın mevcut olduğu görülmektedir. Chiuchisan ve arkadaşlarının yapmış oldukları çalışmada Yoğun Bakım Ünitelerinde risk altındaki hastaların izlenmesi için bir akıllı sağlık sisteminin genel bir mimarisi önerilmektedir. Ayrıca çalışmada Sistem doktorlara/sağlık görevlilerine hayati parametrelerin değişimi veya hastaların hareketleri ve ayrıca çevresel parametrelerde önleyici önlemler almak için önemli değişiklikler konusunda tavsiyelerde bulunulmaktadır (Chiuchisan, Costin, \& Geman, 2014). Lee ve Ouyang'ın yapmış oldukları çalışmada sağlık hizmetlerinin Nesnelerin İnterneti tabanlı kişisel sağlık cihazları ile etkili geri bildirim sağlaması için bir model sunulmuştur. Bu model içerisinde Nesnelerin İnterneti kişisel sağlık cihazları arasında risk faktörlerini transfer etmesi için işbirliği protokolü geliştirilmiştir (Lee \& Ouyang, 2014). Nesnelerin İnterneti tabanlı sağlık bakım sistemlerinin geliştirilmesi, hastaların güvenliğini, yaşam kalitesini ve diğer sağlık hizmetleri faaliyetlerini sağlamalı ve arttırmalıdır. Sağlık Hizmetlerinde geliştirilmesi hedeflenen yönlerin belirlenebilmesi için Kalite Fonksiyonu Göçerimi metodunun kullanılması ile ortaya çıkan Kalite Evi ile yapının ortaya konması eksiklerin ve nasıl giderileceklerinin anlaşılması açısından kolaylık sağlamaktadır.

Yapılan çalışmalar incelendiğinde Kalite Fonksiyonu Göçerimi yönteminin sağlık hizmetlerinin iyileştirilmesinde kullanılmasına karşın Nesnelerin İnterneti kullanılarak bir çözüm önerisi sunulmadığı görülmüştür. Bu çalışmanın amacı, Kalite Fonksiyonu Göçerimi yöntemi uygulanarak bir hastanenin hizmetlerindeki eksikler belirlenmeye çalışılarak Nesnelerin İnterneti ile bu eksiklerin giderilmesini sağlayacak bir model önerisi sunmaktır.

\section{Materyal ve Metot}

Bir kamu hastanesinin daha kaliteli bir hizmet sunması için günümüz teknolojilerinden Nesnelerin İnternet'ini kullanmasının hangi ihtiyaçları karşılayacağını görmek üzere bu çalışma yapılmıştır. Müşteri ihtiyaçlarının Servqual yardımıyla hazırlanan bir ölçek ile uzman ekip danışmanlığı tarafından belirlendiği çalışmada, bu ihtiyaçlara Nesnelerin İnterneti kapsamında önerilebilecek teknik gereksinimler belirlenmiş ve Kalite Fonksiyonu Göçerimi yöntemi uygulanmıştır. Ortaya çıkan Kalite Evi incelendiğinde sırasıyla en yüksek teknik önem derecesine 
sahip teknik gereksinimlerin karşılanabilmesi için Nesnelerin İnterneti teknolojisi ile bir model geliştirilmiştir.

\subsection{Hizmet Kalitesi}

Bir tanıma göre hizmet "bireylerin ihtiyaçlarını karşılamak amacıyla elle tutulamayan, koklanamayan, mallardan ve başka hizmetlerden bağımsız olarak satışa sunulan, standartlaştırılamayan, fayda ve doyum oluşturan, soyut faaliyetler bütünü” olarak tanımlanmıştır (Değer, 2012, s. 4). Üretim süreci içerisinde yapılan bir tanımda hizmet "insan ve makineler tarafından insanların faydası için üretilen, üretim ve tüketiminin eş zamanlı olduğu, heterojen nitelikte ve fiziksel olmayan ürünlerdir" şekilde ifade edilmiştir (Savaş \& Kesmez, 2014, s. 2). Bir başka tanımda ise hizmet müşteri ile hizmeti sunan kişi ya da kurumun karşılıklı olarak birbirleri ile iletişim kurmalarını gerektiren sosyal faaliyetler olarak tanımlanmıştır (Karahan, 2000). Hizmetin birçok farklı tanımının bulunuyor olması sahip olduğu özelliklerden kaynaklanmaktadır. Hizmeti mallardan ayıran bu özellikler; soyutluluk, ayrılmazlık (üretimle tüketimin birbirinden ayrılmaz olması), değişkenlik, heterojenlik ve dayanıksızlık olarak siralanabilmektedir (Değer, 2012, s. 4) (Rahman, Erdem, \& Devebakan, 2007, s. 39).

Sanayi Devrimi ile birlikte seri üretimlerin gerçekleşmesi, ilk kez kalite kavramını ortaya çıkarmıştır. İlk başlarda kalite; dayanıklılık, mükemmellik derecesi olarak karşımıza çıkmaktadır. Fakat yıllar içerisinde kullanım amacına göre farklı anlamlar taşıyabilmektedir. Temel olarak Latince "qualitas" sözcüğünden türemiştir. Qualitas, bir şeyin nasıl oluştuğu anlamına gelmektedir (Değer, 2012).

Kalitenin tanımında tüketici odaklı ifadelerin ön plana çıktığı görülmektedir. $\mathrm{Bu}$ tanımlardan bazıları "müşterinin sürekli değişen istek ve ihtiyaçlarının karşılanması ya da geçilmesi”, "her türlü hata ve kusurlardan beri olmak", "müşteriye sunulan ürün veya hizmetin, o müşteriler tarafindan belirlenen veya daha sonra ortaya çıkabilecek ihtiyaçlarını karşılama yeteneğine dayanan özelliklerinin bütünü” şeklindedir (Savaş \& Kesmez, 2014).

Hizmet Kalitesi; hizmet kavramının sahip olduğu temel özellikleri nedeniyle müşterilerin kalite algısını ve müşteri tatminini büyük ölçüde etkilemektedir. Hizmet kalitesi bir ürün veya hizmetin üstünlüğü ya da mükemmelliği ile ilgili müşterinin genel yargısı, müşterinin hizmet kalitesine olan sezgileri olarak karşımıza çıkmaktadır (Devebakan \& Aksaraylı, 2003, s. 40).

Kaliteyi oluşturan unsurlar kalitenin tanımlanmasını zorlaştırmaktadır. Yapılan birçok çalışmada kalitenin unsurları incelenmiş ve bu unsurlar doğrultusundan müşteri beklentileri doğru belirlenmek istenmiştir. Hizmet kalitesinin tüketiciler tarafından nasıl algılandığını tanımlamak ve hizmet kalitesinin ne şekilde etkilediğini belirlemek hizmet şirketlerinin gelecekte başarılı bir şekilde rekabet edebilmeleri ve geliştirebilmeleri için gereklidir (Grönroos, 1983).

Hizmet Kalitesi boyutlarını model olarak ele alan ilk çalışma Grönoors'un çalışmasıdır. Görnoors tarafından geliştirilen Hizmet Kalitesi Modeli 1985 yılında Parasuraman ve arkadaşları tarafından geliştirilmiştir. Parasuraman ve arkadaşlarının ortaya koymuş oldukları "Kavramsal Hizmet Modeli", hizmet kalitesi araştırmalarında en çok kabul gören modeldir. Çalışma, hizmet türü ne olursa olsun, tüketicilerin hizmet kalitesini değerlendirmede temel olarak benzer kriterler kullandıklarını ortaya koymuştur (Parasuraman, Zeithaml, \& Berry, 1985). Bu kriterler Hizmet Kalitesi Boyutları olarak 10 başlık altında ele alınmıştır.

\subsection{Servqual Ölçeği}

Parasuraman ve arkadaşları, tarafindan 22 maddeden oluşan ve "Servqual" olarak adlandırılan detaylı bir ölçme metodu (anket) geliştirilmiştir. Bu yöntem hizmet sunucu tarafından sağlanması beklenen ve müşteri tarafından algılanan kalitenin tüketiciler tarafından değerlendirilmesi esasına dayanan bir anket tekniğidir. Temel olarak, müşteri memnuniyetinin "algılamaların beklentiden farklılaşmasının bir fonksiyonu" olduğunu ileri sürülmektedir. On kalite boyutu, Parasuraman ve arkadaşlarının çalışmasında (1985) tüm hizmet sektörleri için geçerli olabilecek beş hizmet kalitesi boyutuna sadeleştirilmiştir (Parasuraman, Zeithaml, \& Berry, 1985). Bu beş boyut şu şekildedir;

Fiziksel Özellikler (Tangibles): Hizmet sunumundaki fiziksel imkânlar, araç ve gereçler, ortamın ve çalışanların görünüşüdür.

Güvenilirlik (Reliability): Vaat edilen hizmetin zamanında doğru ve güvenilir bir şekilde yerine getirilebilmesidir.

Heveslilik (Responsiveness): Hizmet sağlanırken hızlı ve yardım sever bir yaklaşım izlenilmesidir.

Güven (Assurance): Hizmet verilirken karşı tarafa nazik davranılması ve güven duygusu uyandırılabilmesidir. Çalışanların bilgi ve becerileri müşterilerde güven duygusu uyandırabilmek için önemlidir.

Empati (Empathy): Hizmet sağlayıcıların kendilerini müşterilerin yerine koyup en yüksek faydayı sağlamak için gereken çabayı göstermeleridir.

Servqual'ın çıkış amacı kurumların mükemmel hizmeti sağlayabilmesi için tüketicilerin beklentilerini anlayabilmek, beklentileri bu doğrultuda karşılayabilmek ve beklentilerin üstüne çıkabilmeyi başarabilmektir. Servqual analizi yapılırken hizmet kalitesinin beş boyutu etrafında oluşturulan ifadelere verilen cevaplar ile bir değerlendirmede bulunulur. Sorulara verilen yanıtlar beklenen hizmet ve algılanan hizmet olarak iki kısımda istenmektedir. Beklenen hizmet ile ilgili kısımda müşterilerin mükemmel bir sistemden beklediği yönleri sorgulayan ifadeler yer almaktadir.

\section{Servqual Puanı $=$ Algılanan Puan - Beklenti Puanı}

Yukarıda verilen formül kullanılarak her bir soru önermesi için Servqual puanı hesaplanmaktadır. Her bir soru önermesi 7'li bazen 5'li Likert ölçeği üzerinden verilen puanlarla, algılar ve beklentiler arasındaki fark ortaya konulmaktadır. Her bir soru önermesi için -6 ile +6 (7’li Likert ölçeği kullanılmışsa) veya -4 ile +4 (5'li Likert ölçeği kullanılmışsa) arasında değişen Servqual puanları hesaplanmaktadır (Rahman, Erdem, \& Devebakan, 2007).

Çalışmada hastane bilgi sistemleri üzerinde uzman kişilerden oluşan bir gruba Servqual ile hazırlanmış bir ölçek sunulmuştur. Elde edilen veriler ile Kalite Fonksiyonu Göçerimi yönteminde müşteri ihtiyaçları oluşturulmuştur.

\subsection{Kalite Fonksiyonu Göçerimi}

.Japonya'da 1972 yılında otomotiv sektöründe doğan kalite fonksiyonu göçerimi, daha sonraki yıllarda ABD'de incelenen ve kullanılan ve bugün tüm dünyada kabul gören bir kalite tekniği halini almıştır (13 s. 71). 
Müşteri istek ve beklentilerini nicelleştiren, hizmetlerin tasarımı, üretimi ve pazarlanması amacı ile işletme içindeki kaynak ve beceriler üzerinde yoğunlaşarak gerekli koordinasyonu sağlayan bir dizi planlama ve iletişim sürecinden oluşmaktadır. $\mathrm{Bu}$ beklentileri tasarım ve üretim sürecinin tümüne yansıtan sistematik bir yaklaşımdır. Bu yaklaşım ile örgütün işlevsel bölümlerinde tespit edilen eksiklikler iletilerek mal ya da hizmet özelliklerine dönüştürülmektedir. Kalite fonksiyonu göçerimi, bazı çalışmalarda kalite fonksiyonu yayılımı olarak da geçmektedir (14).

Kalite Fonksiyonu Göçerimi "Kalite evi" adı verilen kavramsal bir şema aracılığı ile ürün geliştirme ve iyileştirme işlemini, bir matris üzerinde müşterinin performans beklentilerini teknik tasarım karakteristikleriyle ilişkilendirerek gerçekleştirmektedir. Müşteri beklentileri ve teknik özellikler arasındaki bu ilişkilendirme, her bir özelliğin müşteri beklentilerine yapacağı etkileri gösteren nicel bir ölçüt geliştirilmesini sağlamaktadır (15).

KFG sisteminin uygulamadaki başarısının önemli bir şartı, süreci oluşturacak faaliyet dizgesinin ayrıntılı olarak planlanması ve her bir faaliyet adımının zamanlanmasıdır. Çünkü "KFG bir araç değil, bir işletmeye, diğer teknik araçların birbirlerini destekleyecek ve tamamlayacak şekilde etkin olarak kullanımında ve öncelikli konuların ortaya konmasında yardımcı olan bir planlama prosesidir." (13 s. 72).

Bir çalışmada Kalite Fonksiyonu Göçerimi metodu ile başlangıç aşamasında karşılaşılan problemlerin büyük bir kısmının azaldığı ve ürün geliştirme zamanının \%66 oranında kısaldığı ortaya koyulmuştur. Ayrıca tasarım kararlarının ürünün yaşam çevrimi boyunca ortaya çıkacak olan maliyetleri etkilemesi sebebiyle ürün tasarımcıları KFG'yi süreçlerinde kullanmaya başlamışlardır (13).

Bir organizasyonda KFG sistemi dört aşamada kurulmaktadır. Bunlar; Planlama, Müşteri Beklentisinin Toplanması, Kalite Evi'nin oluşturulması ve Sonuçların Analizi adımlarıdır. Planlama aşamasında sistemin amaçları açık ve net olarak belirlenmeli, kesin sınırlar ile tanımlanmalıdır.

KFG'nin ilk kullanım alanının endüstri ürünleri tasarımı olduğu görülmektedir. Ancak sonraki yıllarda yöntemin farklı alanlarda da kullanılabilir olduğu görülmüştür. Yöntemin sunduğu Kalite Evi olarak bilinen grafiksel gösterim, net bir iletişim sağlayarak geleneksel dokümanlara kıyasla temel gerçeklerin hızlı ve daha anlaşılır olmasını sağlamaktadır (16).

Birçok yöntemde olduğu gibi Kalite Fonksiyonu Göçerimi yöntemi de sıralı adımlardan oluşmaktadır. Sürecin başarıya ulaşması için birbiri ile uyum içinde olan bu aşamaların doğru anlaşılması gereklidir. İlk adım " 0 ”" ile ifade edilmek üzere süreci oluşturan 4 aşama vardır. Bu aşamalar şu şekildedir:

- Aşama 0: Planlama

- Aşama 1: Müşterinin Sesinin Toplanması

- Aşama 2: Kalite Evinin Oluşturulması

- Aşama 3: Sonuçların Analizi ve Yorumlanması
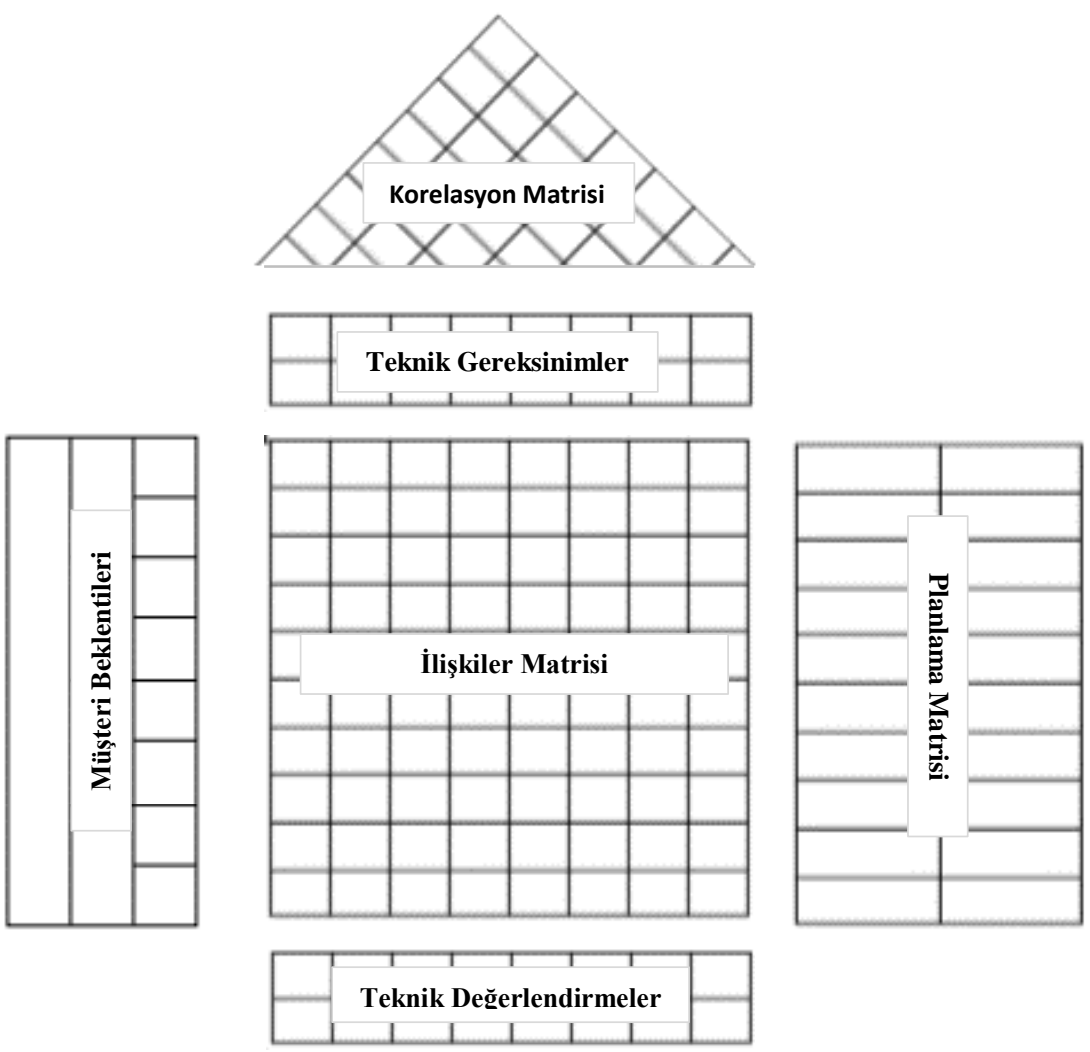

\section{Şekil 1. Kalite Evi Unsurlart}

Bir takım matrislerden oluşan Kalite Evi, kalite fonksiyon dağıtımında (QFD) iyileştirme sürecinin planlanmasına yönelik ilk adımdır. Şekil 1'de Kalite Evi'ni oluşturan matrisler ve yerleri gösterilmektedir. Kalite Evi matrisi, ürün ve hizmet bilgilerinin e-ISSN: 2148-2683 özetini göstermektedir. Bu nedenle ortaya konulan matrisler iyileştirme prosesinde yön gösterici grafiksel sistematik bir yöntemdir (Güllü \& Ulcay, 2002). 
- Kalite Evi şu aşamalardan oluşmaktadır;

- Müşteri Beklentilerini Belirleme,

- Planlama/Rekabet Matrisinin Oluşturulması,

- Teknik Gereksinimlerin Belirlenmesi,

- Müşteri İhtiyaçları İle Teknik Gereksinimler Arasındaki İlişkilerin Belirlenmesi,

- Teknik Gereksinimlerin Korelasyonunun Belirlenmesi,

- Teknik Gereksinimlerin Önem Derecelerinin Belirlenmesi

\subsection{Nesnelerin İnterneti (IoT)}

İnternet, dünya çapında milyarlarca kullanıcıya hizmet vermek için standart internet protokol paketini (TCP/IP) kullanan, birbirine bağlı bilgisayar ağlarının küresel bir sistemidir. $\mathrm{Bu}$ sistem sayesinde insanların etkileşimleri artmış ve bilgi çağının ötesine geçilmiştir. Geçmişte internet kullanımı insanların erişimi ile bilgi alışverişi ile sınırlı iken günümüzde ise bilgi alışverişinin insanlarla sınırlı kalmadığı, bilgisayarların ve birbirlerine bağlı nesnelerin de bilgi alışverişi içerisinde olduğu görülmektedir.

Nesnelerin İnterneti standart iletişim protokolleri ile dünya genelinde birbirlerine bağlı nesnelerin benzersiz bir şekilde adreslenebilmelerini sağlamaktadır. Fiziksel Nesnelerin birbirleriyle ya da daha büyük sistemlerle bağlantılı olduğu iletişim ağı olarak tanımlanabilen Nesnelerin İnterneti kavramı, ilk olarak Kevin Ashton tarafından Procter\&Gamble şirketi için hazırlanan RFID (Radio Frequency Identification) teknolojisinin faydalarının anlatıldığı bir sunumda kullanılmıştır (Özdemir, Naralan Nursaçan, \& Nursaçan, 2018).
Nesnelerin İnterneti (IoT), kablosuz iletişim ve düşük maliyetli sensörler, bilgi işlem ve depolama aygıtları kullanarak uzak ve mobil şeyleri veya makineleri veya varlıkları bağlama yeteneği sayesinde "İnternet'in yeni bir devrimidir". Dolayısıyla, internet artık bir bilgisayar ağından bir nesneler ağına doğru ilerlemektedir. Temel IoT bileşenleri olarak, RFID sistemleri, kablosuz algılayıcı ağlar, adresleme şemaları, veri depolama ve görüntüleme sistemleri sayılabilmektedir (AKTAŞ, ÇEKEN, \& ERDEMLİ, 2016).

Nesnelerin İnternet'inin temelini oluşturan RFID, Radyo dalgalarını kullanarak canlıları veya nesneleri tanımlayan teknolojilere verilen genel bir isimdir. Bir etiket ve okuyucudan oluşan RFID, okuyucu ile etiket arasında elektromanyetik dalgalar aracılığıyla iletişim kurulmaktadır (Aktaş, Çeken, \& Erdemli, 2014, s. 300). RFID teknolojisi uzak mesafeden görüş hattı gerektirmeden tanımlamayı sağlamaktadır. Bu teknolojinin sahip olduğu elektronik etiketler bir kaç bayttan kilobayta kadar değişik uzunlukta veri saklayabilmektedirler (KILINÇ, 2007, s. 6). RFID etiketleri, barkodlardan daha büyük bir benzersiz kimlik kümesini destekler, üretici, ürün tipi gibi ek veriler içerebilir ve hatta sıcaklık gibi çevresel faktörleri de ölçebilir (Want, 2006). RFID etiketleri ile IoT teknolojisinin temeli atılmıştır. RFID etiketlerinin sağlık sisteminde kullanılması ile birlikte hasta bilgileri etiket üzerine yazılarak, istenildiği zaman bilgilere otomatik erişilmesi mümkün olmaktadır. RFID'nin hastane sistemleri içerisinde kullanımına bir örnek Şekil 2'de verilmiştir. $\mathrm{Bu}$ sayede hasta takibi kolay bir şekilde gerçekleştirilebilmektedir.
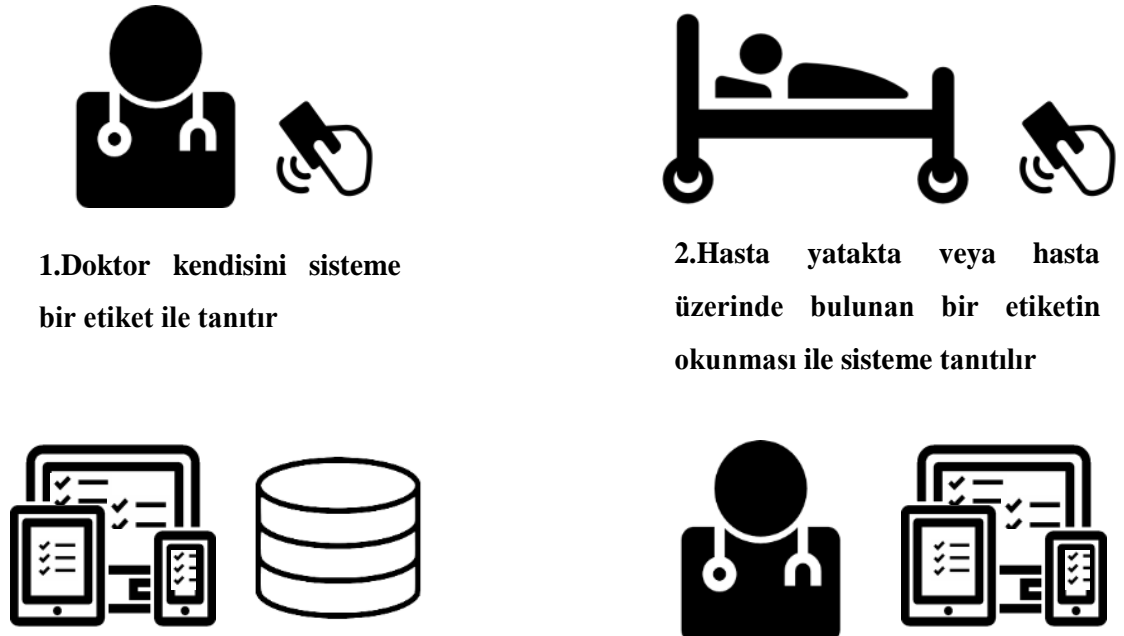

\author{
3.Hasta Bilgileri Elektronik \\ cihaza taşınır ve veritabanı \\ bağlantısı kurulur
}

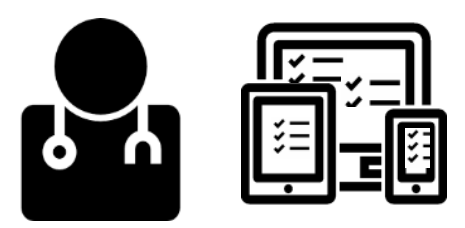

4.Doktor yapılacak tetkikleri ve teşhisleri elektronik cihazına girer.

\section{Şekil 2. RFID ile Hasta Takip Sistemi}

Günümüzde kablosuz teknolojilerin göstermiş olduğu gelişimle birlikte küçük boyutlarda, güç tüketimi az olan, çok fonksiyonlu algılayıcı elemanlar tasarlanabilmektedir. $\mathrm{Bu}$ elemanların oluşturdukları ağlar Kablosuz Algılayıcı Ağlar (KAA) olarak adlandırılmaktadır (Ökdem \& Karaboğa, 2007). KAA, dış ortama ait 1şık, sıcaklık, basınç, ses, hareket vb. birçok fiziksel büyüklüğü toplama, toplanan verileri işleme ve haberleşme yapabilme becerisine sahip düğümlerden oluşan bir ağ sistemidir (Aktaş, Çeken, \& Erdemli, 2014).

Kablosuz teknolojilerin en büyük avantajı sağlık hizmetlerinin sağlık tesisleri dışında da verilebilmesine imkân sağlamasıdır. Temel olarak algılayıcılar (sensör düğüm) ve bu algılayıcılardan gelen verileri toparlayan düğüm istasyonlarından 
oluşmakta olan bu ağların enerji kaynakları sınırlı olup değiştirilememektedir (Ökdem \& Karaboğa, 2007; Türker \& Tarımer, 2011). Genellikle ağ içerisinde, konumları önceden belirlenmemiş rastgele ortama saçılmış olarak hareketli ve sabit pozisyonlu algılayıcılar bulunabilmektedir (Türker \& Tarımer, 2011).

KAA'ların ortaya çıkarmış olduğu Kablosuz Vücut Alan Ağları ile birlikte bireylere ait fizyolojik veriler toplanabilmektedir. Nesnelerin birbirleriyle ve insan vücuduyla entegre bir şekilde çalışması ile giyilebilir teknolojiler kavramı ortaya çıkmıştır. Şekil 3'de Nesnelerin İnterneti ve akıllı cihazların oluşturduğu bir ağ şeması verilmiştir. Bir ürünün giyilebilir teknoloji sayılabilmesi için sensörler yardımı ile toplanmış olan verinin bluetooth veya kablosuz teknolojiler ile başka bir ortama aktarılması gerekmektedir (Sönmez Çakır, Aytekin, \& Tümçin, 2018). Giyilebilir teknolojilerin getirdiği avantajlardan birçok sektör gibi sağlık hizmetleri sektörü de faydalanmaktadır.

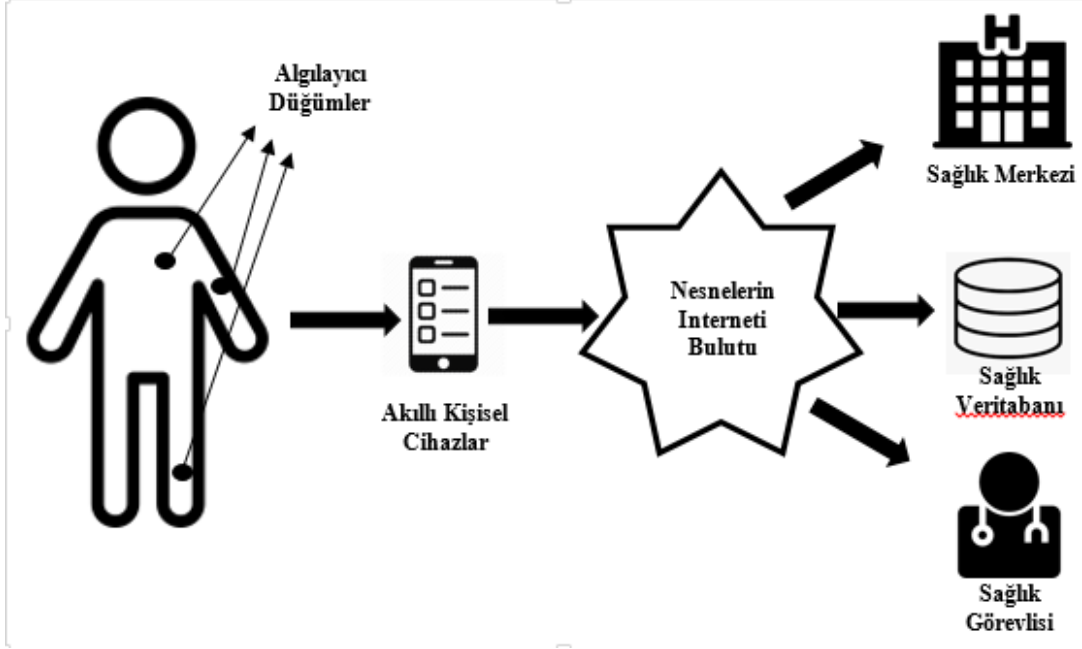

Şekil 3. Kablosuz Vücut Alan Ağları Şeması

Nesnelerin interneti altyapısı ile kronik hastalıklar uzaktan takip edilerek ölçümler anında doktor ve hasta yakınları ile paylaşılabilmektedir. Bu şekilde ölçümler düzenli takip edilerek hastalıkların yol açtığı istenmeyen durumlar tam zamanında engellenebilmektedir. Son yıllarda giyilebilir teknolojilerdeki gelişim ile kişisel sağlık hizmetleri de beraberinde gelişmiştir. Sağlık sektörü gibi bilgi yoğunluğu olan sektörlerde Nesnelerin Interneti potansiyeline daha uygun uygulamalar ortaya konulmaktadır (Xu, ve diğerleri, 2014). Bulut Teknolojisi bunlardan birisidir. Bulut, ölçeklenerek yatay veya dikey olarak büyüyebilen, hesaplanabilen bilgi ve iletişism teknolojileri için uzaktan erişilebilmesi için tasarlanmış ayrı bir bilişim teknolojileri ortamını ifade etmektedir. Bulut bilişim sistemlerinin sağlamış olduğu yüksek oranda ölçeklenebilir ve yüksek oranda erişilebilirlik ile düşük maliyetler ile maksimum fayda sağlanabilmektedir. Şekil 4'de Bulut Bilişim ve Nesnelerin İnterneti'nin bir arada nasıl işlediği örnek olarak gösterilmektedir.

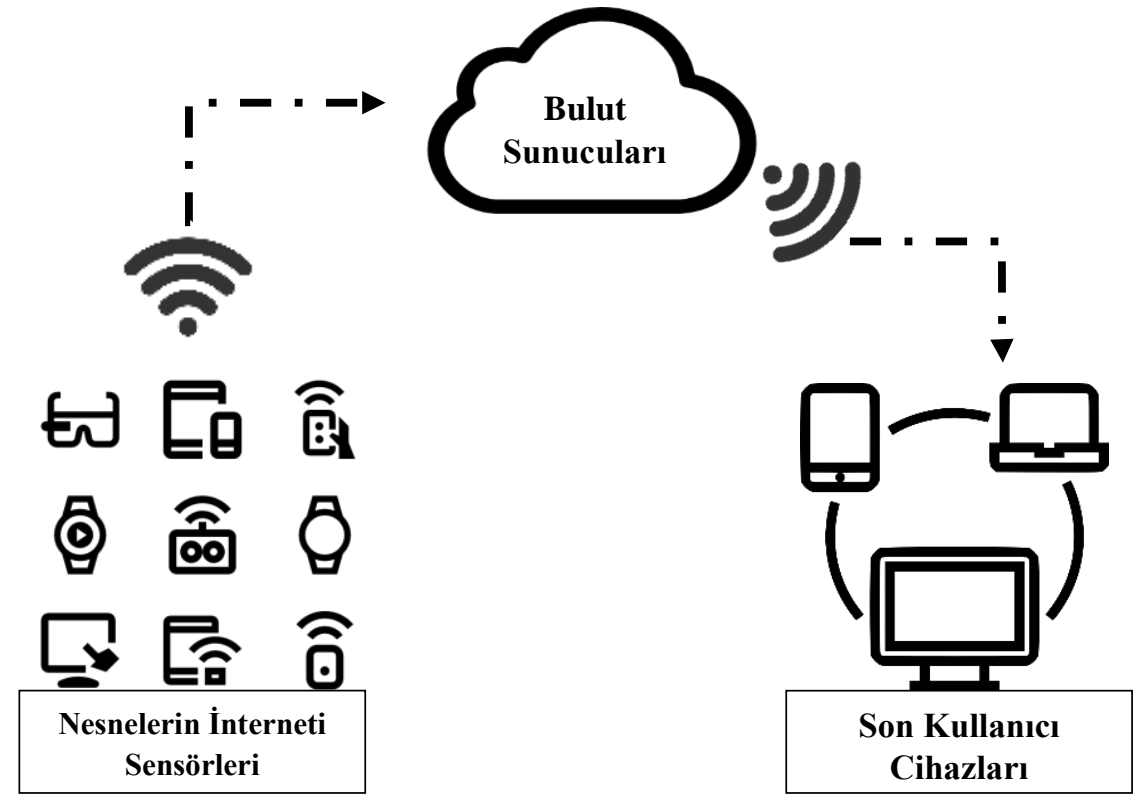

Şekil 4. Nesnelerin İnterneti ve Bulut Bilişim Diyagramı

Dar Bant Nesnelerin İnterneti (NB-IoT), az miktarda veri göndermek ve almak için yüksek bağlantı yoğunluklu cihazlar için kullanmaktır. Düşük güçlü geniş alan ağlarından(Low Power
Wide Area Networks-LPWAN) yararlanan hizmetler temel olarak derin/geniş kapsama alanı, düşük güç tüketimi ve büyük bağlantılar gerektirir. $\mathrm{Bu}$ teknoloji GSM firmaları tarafından 
Nesnelerin İnterneti teknolojisi için hücresel bağlantı altyapısını kullanan ve lisanslı frekanslarda çalışan bir iletişim teknolojisidir. GSM'den 20dB daha fazla çekim alanı 10 yıl süren pil ömrü ve hücre başına elli bin bağlantı garanti etmektedir (Huawei Technology Cooperation, 2015). GSM operatörlerine bağımlılığından dolayı NB-IoT hücresel veri kullanmakta ve SIM kartına ihtiyaç duymaktadır.

Geçtiğimiz birkaç yıl içinde birbirine bağlı giyilebilir ürünler, ağırlıklı olarak sağlık ve sağlıklı yaşam etrafinda dönen bir uygulama olduğu için giderek kârlı bir endüstri haline gelmiştir. Cihazın bir NB-IOT yonga seti ile gömülü olması durumunda, faydalar şaşırtıcıdır. Örneğin, büyük veri analizindeki iyileştirmeler sayesinde yönetim daha verimli hale gelmektedir. Nesnelerin İnterneti cihazı temel olarak, yerel alanda bulunan sensörler ve cihazlar aracılığıyla kullanıcıya istihbarat sağlamayı amaçlayan LPWA uygulamalarından oluşmaktadır. Düşük güç tüketimi, akıllı sayaç, akıllı park etme ve giyilebilir cihazlar gibi uygulamalardan akıllı şebekeye kadar tüm LPWA kullanım durumlarının neredeyse \% 80'i için bir ön koşuldur. Bu nedenle NB-IoT, LPWAN alanları için iyi bir çözümdür (Huawei Technology Cooperation, 2015).

\section{Araştırma Sonuçları ve Tartışma}

\subsection{Servqual Ölçeğinin Analizi}

Bu çalışmada teknik bilgi birikimine sahip ve hastane bilgi işlem merkezinde çalışan 15 uzman kişiye Servqual Hizmet Kalitesi Ölçeği ile hazırlanmış sorular yöneltilerek müşteri sesi dinlenilmek istenmiştir. Aşağıda uzmanlara sorulan sorular ve elde edilen ortalama değerler verilmektedir. $P(n)=(n)$ ifade için Servqual Puan1, A(n)= Alg1 ifadesinin puanın1, B(n)= Beklenti ifadesinin puanını göstermektedir. Servqual Puanı Algılama Puanı-Beklenti Puanı olarak belirlendiğinden Servqual Puanının pozitif bulunması, müşteri beklentilerinin karşılandığ 1 ve aşıldı̆̆ 1 ; dolayısıyla hastane hizmetlerinde kaliteli hizmet anlayışının hâkim olduğu yorumu yapılabilmektedir.

Tablo 1. Müşterilerin Beklenti ve Algılamaları Arasındaki Farkın Ölçümü

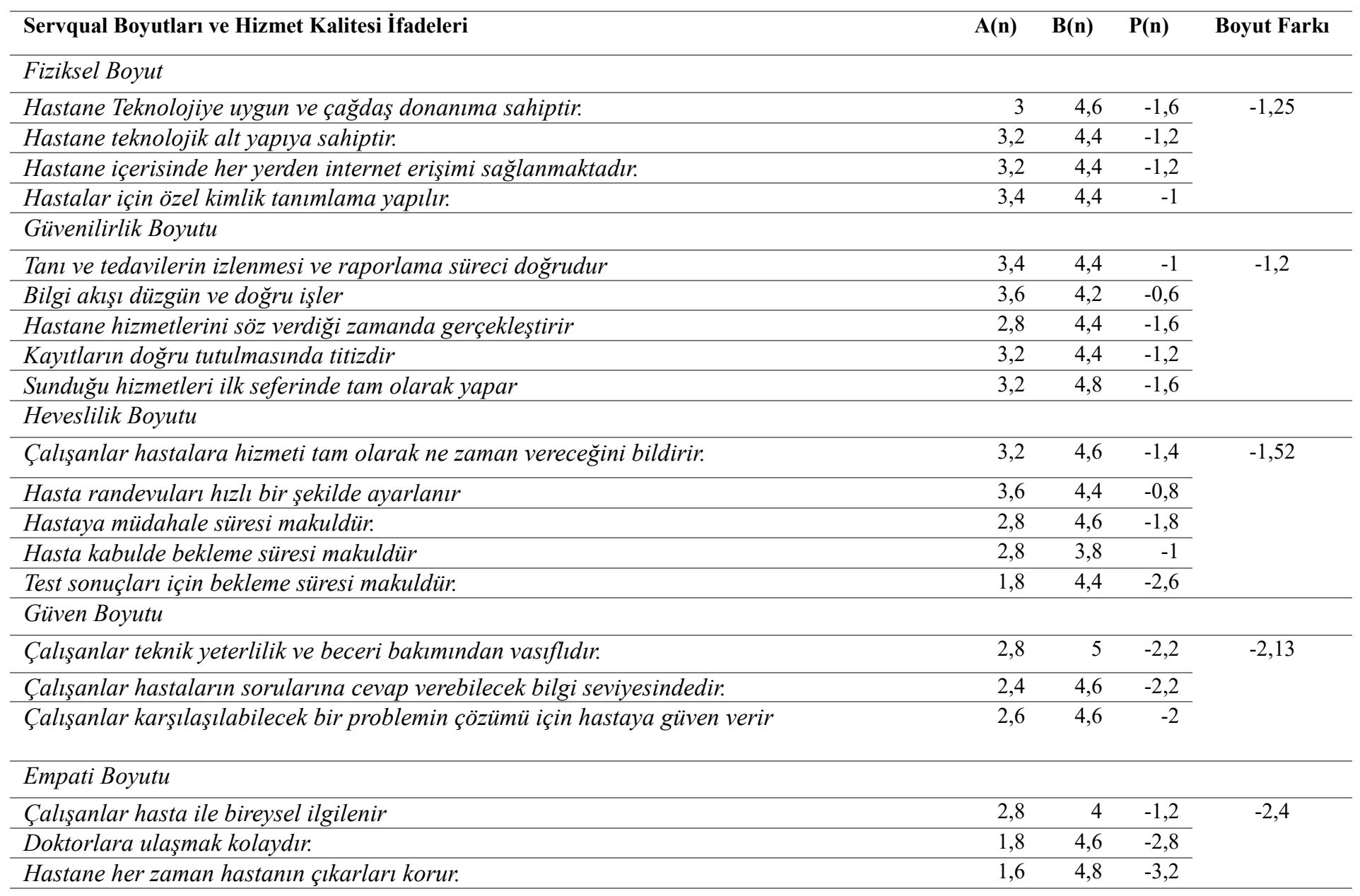


Ancak Tablo 1'de görüldüğü üzere hastane hizmetlerinde pozitif bir değer bulunmamaktadır. Hastane hizmetlerinde en büyük eksikliğin Güven ve Empati Boyutunda olduğu görülmektedir. İfade bazında bakıldığında ise en büyük açığın
"Hasta çıkarlarının korunması" hizmetinde olduğu görülmektedir. Yine ifade bazında bakıldığında beklenilen hizmetin en yakın karşılandığı hizmetin "Bilgi akışının doğru ve düzgün işlemesi"”, olduğu görülmektedir.

Tablo 2. Hizmet Kalitesi Ífadelerinin Önem Derecesi

\begin{tabular}{l|c|c|}
\hline \multicolumn{1}{|c|}{ Hizmet Kalitesi İfadeleri } & Önem Dereceleri & Boyut Ortalamas \\
\hline Fiziksel 1. & 4,8 & 4,62 \\
\hline Fiziksel 2. & 4,6 & \\
\hline Fiziksel 3. & 4,7 & 4,48 \\
\hline Fiziksel 4. & 4,4 & \\
\hline Güvenilirlik 1. & 4,8 & \\
\hline Güvenilirlik 2. & 4,4 & 4,4 \\
\hline Güvenilirlik 3. & 4,8 & \\
\hline Güvenilirlik 4. & 4,4 & \\
\hline Güvenilirlik 5. & 4 & \\
\hline Heveslilik 1. & 4,4 & \\
\hline Heveslilik 2. & 4,2 & 4,6 \\
\hline Heveslilik 3. & 4,6 & \\
\hline Heveslilik 4. & 4,2 & \\
\hline Heveslilik 5. & 4,6 & 4,73 \\
\hline Güven 1. & 4,6 & \\
\hline Güven 2. & 5 & \\
\hline Güven 3. & 4,4 \\
\hline Empati 1. & 4,4 \\
\hline Empati 2. & 4,8 \\
\hline Empati 3. & 5 & \\
\hline & & \\
\hline
\end{tabular}

Tablo 2'de ele alınan önem dereceleri incelendiğinde en yüksek önem derecesine sahip hizmet boyutunun Empati Boyutu olduğu görülmektedir. Tablo 1 ve Tablo 2 birlikte ele alınarak yorumlanmak gerekirse; en yüksek önem derecesine ve en büyük hizmet açığına sahip olan hizmet boyutunun Empati Boyutu olması sebebi ile hizmet kalitesinin iyileştirilmesi gerekliliği en çok bu boyutta ortaya çıkmaktadır.

Servqual çalışması sonucunda elde edilen bilgiler ile Kalite Evi içerisinde müşteri ihtiyaçları ve önem düzeyleri yerleştirilmiştir.

\subsection{Kalite Fonksiyonu Göçerimi ile Kalite Evinin Oluşturulması}

Kalite Evi matrisi ile görselleştirilmiş olan bilgiler iyileştirme prosesinde yön gösterici olmaktadır. Belirlenen ihtiyaçlar doğrultusunda Kalite Evi aşamaları sırasıyla izlenmiştir.

1- Müşteri beklentilerinin belirlenmesi ve önem derecesine göre sıralanması: Servqual analizi yardımıyla oluşturulan hastane ihtiyaçları ve önem dereceleri belirlenmiştir. Beklenen ve algılanan hizmet puanları hesaplanmış bu puanlar yardımıyla daha önce de belirtilen şekilde Servqual Skoru hesaplanmış, Servqual Skoru ve önem düzeyinin çarpımı sonucunda da müşteri memnuniyet puanı elde edilmiştir. Belirtilen değerler Tablo 3'de bir arada verilmiştir. Değerlerin tamamı negatif olduğu için tüm ifadeler Kalite Evinde yer almıştır.

Tablo 3. Hastane Hizmeti ile İlgili İhtiyaçların Önem Düzeyi

\begin{tabular}{|c|c|c|c|c|c|}
\hline Gereksinimler & $\begin{array}{l}\text { Önem } \\
\text { Düzeyi }\end{array}$ & $\begin{array}{c}\text { Algılanan } \\
\text { Hizmet Puanı } \\
\end{array}$ & $\begin{array}{c}\text { Beklenilen } \\
\text { Hizmet Puanı } \\
\end{array}$ & $\begin{array}{l}\text { Servqual } \\
\text { Puanı } \\
\end{array}$ & Memnuniyet Puanı \\
\hline $\begin{array}{l}\text { Teknolojiye uygun ve çăgdaş donanıma } \\
\text { sahiplik }\end{array}$ & 4,8 & 3 & 4,6 & $-1,6$ & $-7,68$ \\
\hline Teknolojik alt yapıya sahiplik & 4,6 & 3,2 & 4,4 & $-1,2$ & $-5,52$ \\
\hline Her yerden internet erişimi & 4,7 & 3,2 & 4,4 & $-1,2$ & $-5,64$ \\
\hline Hastalar için özel kimlik tanımlama & 4,4 & 3,4 & 4,4 & -1 & $-4,4$ \\
\hline $\begin{array}{l}\text { Tanı ve tedavilerin izlenmesi ve raporlama } \\
\text { süreci doğruluğu }\end{array}$ & 4,8 & 3,4 & 4,4 & -1 & $-4,8$ \\
\hline Bilgi akışı düzgün ve doğru işlemesi & 4,4 & 3,6 & 4,2 & $-0,6$ & $-2,64$ \\
\hline
\end{tabular}


(Tablo 3 devami)

\begin{tabular}{|c|c|c|c|c|c|}
\hline $\begin{array}{l}\text { Hastane hizmetlerini söz verdiği zamanda } \\
\text { gerçekleştirme }\end{array}$ & 4,8 & 2,8 & 4,4 & $-1,6$ & $-7,68$ \\
\hline Kayıtların doğru tutulmasında titizlik & 4,4 & 3,2 & 4,4 & $-1,2$ & $-5,28$ \\
\hline $\begin{array}{l}\text { Sunulan hizmetleri ilk seferinde tam olarak } \\
\text { yapma }\end{array}$ & 4 & 3,2 & 4,8 & $-1,6$ & $-6,4$ \\
\hline $\begin{array}{l}\text { Hastalara hizmetin tam olarak ne zaman } \\
\text { verileceği bildirilmesi }\end{array}$ & 4,4 & 3,2 & 4,6 & $-1,4$ & $-6,16$ \\
\hline Randevuların hizlı ayarlanması & 4,2 & 3,6 & 4,4 & $-0,8$ & $-3,36$ \\
\hline Hastaya müdahale süresi makullüğ̈̈ & 4,6 & 2,8 & 4,6 & $-1,8$ & $-8,28$ \\
\hline Hasta kabulde bekleme süresi makullüğ̈̈ & 4,2 & 2,8 & 3,8 & -1 & $-4,2$ \\
\hline Test sonuçları için bekleme süresi makullüğü & 4,6 & 1,8 & 4,4 & $-2,6$ & $-11,96$ \\
\hline $\begin{array}{l}\text { Teknik yeterlilik ve beceri bakımından } \\
\text { vasıflılık }\end{array}$ & 4,6 & 2,8 & 5 & $-2,2$ & $-10,12$ \\
\hline $\begin{array}{l}\text { Hastaların sorularına cevap verebilecek bilgi } \\
\text { seviyesi }\end{array}$ & 5 & 2,4 & 4,6 & $-2,2$ & -11 \\
\hline $\begin{array}{l}\text { Karşılaşılabilecek bir problemin çözümü için } \\
\text { hastaya güven verilmesi }\end{array}$ & 4,4 & 2,6 & 4,6 & -2 & $-8,8$ \\
\hline Hastalar ile bireysel ilgilenilme & 4,4 & 2,8 & 4 & $-1,2$ & $-5,28$ \\
\hline Doktorlara ulaşım kolaylığ & 4,8 & 1,8 & 4,6 & $-2,8$ & $-13,44$ \\
\hline Hastanın çıkarlarının korunması & 5 & 1,6 & 4,8 & $-3,2$ & -16 \\
\hline
\end{tabular}

2- Planlama matrisinin oluşturulması: Matris aşağıdaki şekilde oluşturulur;

Müşteri İhtiyaçları: Belirlenen ihtiyaçlar kısaltılarak Müşteri istekleri kısmına yazılır.

Önem Derecesi: Uzman görüşleri ile önem derecesi için elde edilen sonuçların aritmetik ortalaması alınarak planlama matrisinin "Önem Derecesi” sütununa kaydedilir.

Hizmet Bugün: Algılanan Hizmet Puanı olarak ele alınmış olup elde edilen hesaplanan Servqual Algılanan puanları matriste yerleştirilmiştir.

Rakipler: $\mathrm{Bu}$ çalışmada rakipler ile bir karşılaştırma söz konusu olmadığı için ele alınmamıştır.

İşletme Hedefi: Beklenilen Hizmet Puanı olarak ele alınmıştır. Uzmanlarla yapılan Servqual çalışmasında hesaplanan Beklenilen Hizmet puanları matriste yerleştirilmiştir.

İyileştirme Oranı: Beklenilen Hizmet kalitesine ulaşmak için gerek duyulan gelişimin kapsamını temsil etmek üzere yukarıda anlatılmış olan formül kullanılarak hesaplanan değerler matriste yerleştirilmiştir.
Satış Avantajı: Ürün veya hizmette yapılacak olan değişikliğin bir ilerleme getirip getirmeyeceğine bakılması için ele alınır. Bu çalışmada kullanılacak planlama matrisinde Hizmet Sunum Katkısı olarak ele alınmıştır. Hizmet sunumuna katkısına göre puanlar verilmiştir. Verilen puanlar dan 1.5 "Satış potansiyelini çok artırır", 1.2 "Satış potansiyelini artırır", 1.0 "Eski modelden farklı olarak herhangi bir değişiklik yok" anlamına gelmektedir.

Mutlak Ağırlık: İhtiyaçların hesaplanmış önemi olarak ele alınmıştır. Yukarıda anlatıldığı üzere formül kullanılmış ancak çalışmada kullanılacak sütün başlıklarının farklılaştırılmasından ötürü formülün çalışmada kullanılan hali aşağıdaki gibidir.

\section{Mutlak A ğırlık $=$ Önem Derecesi $\times$ Iyileştirme Oranı $\times$ Hizmet Sunum Katkıs}

Yüzde Oran: Her bir müşteri isteğine ait önem puanının, önem puanı sütunu toplamına bölünmesi ile elde edilen değer matriste yerleştirilmiştir.

Bir hastanenin iyileştirilmesi için yapılan bu çalışmada kullanılan planlama matrisi aşağıdaki gibidir.
Müşteri İhtiyacı

Teknolojiye uygun ve çağdaş donanıma sahiplik

Teknolojik alt yapıya sahiplik

Her yerden internet erişimi

Hastalar için özel kimlik tanımlama

e-ISSN: 2148-2683

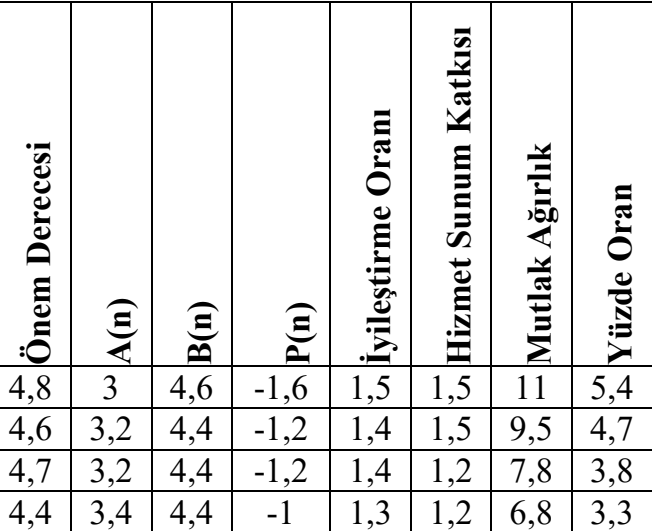

189 
(Tablo 4 devamı)

Tanı ve tedavilerin izlenmesi ve raporlama süreci doğruluğu

Bilgi akışı düzgün ve doğru işlemesi

Hastane hizmetlerini söz verdiği zamanda gerçekleştirme

Kayıtların doğru tutulmasinda titizlik

Sunulan hizmetleri ilk seferinde tam olarak yapma

Hastalara hizmetin tam olarak ne zaman verileceği bildirilmesi

Randevularin hizlı ayarlanması

Hastaya müdahale süresi makullüğü

Hasta kabulde bekleme süresi makullüğ̈̈

Test sonuçlarl için bekleme süresi makullüğ̈̈

Teknik yeterlilik ve beceri bakımından vasıflılık

Hastaların sorularına cevap verebilecek bilgi seviyesi

Karşılaşılabilecek bir problemin çözümü için hastaya güven verilmesi

Hastalar ile bireysel ilgilenilme

Doktorlara ulaşım kolaylığ

Hastanın çıkarlarının korunması

\begin{tabular}{|c|c|c|c|c|c|c|c}
\hline 4,8 & 3,4 & 4,4 & -1 & 1,3 & 1,5 & 9,3 & 4,6 \\
\hline 4,4 & 3,6 & 4,2 & $-0,6$ & 1,2 & 1,5 & 7,7 & 3,8 \\
\hline 4,8 & 2,8 & 4,4 & $-1,6$ & 1,6 & 1,2 & 9,1 & 4,4 \\
\hline 4,4 & 3,2 & 4,4 & $-1,2$ & 1,4 & 1,2 & 7,3 & 3,6 \\
\hline 4 & 3,2 & 4,8 & $-1,6$ & 1,5 & 1,2 & 7,2 & 3,5 \\
\hline 4,4 & 3,2 & 4,6 & $-1,4$ & 1,4 & 1 & 6,3 & 3,1 \\
\hline 4,2 & 3,6 & 4,4 & $-0,8$ & 1,2 & 1,5 & 7,7 & 3,8 \\
\hline 4,6 & 2,8 & 4,6 & $-1,8$ & 1,6 & 1,5 & 11 & 5,6 \\
\hline 4,2 & 2,8 & 3,8 & -1 & 1,4 & 1,5 & 8,6 & 4,2 \\
\hline 4,6 & 1,8 & 4,4 & $-2,6$ & 2,4 & 1,5 & 17 & 8,3 \\
\hline 4,6 & 2,8 & 5 & $-2,2$ & 1,8 & 1,5 & 12 & 6 \\
\hline 5 & 2,4 & 4,6 & $-2,2$ & 1,9 & 1,2 & 12 & 5,6 \\
\hline 4,4 & 2,6 & 4,6 & -2 & 1,8 & 1,2 & 9,3 & 4,6 \\
\hline 4,4 & 2,8 & 4 & $-1,2$ & 1,4 & 1,2 & 7,5 & 3,7 \\
\hline 4,8 & 1,8 & 4,6 & $-2,8$ & 2,6 & 1,2 & 15 & 7,2 \\
\hline 5 & 1,6 & 4,8 & $-3,2$ & 3 & 1,5 & 23 & 11 \\
\hline
\end{tabular}

3-Teknik karakteristiklerin belirlenmesi: Teknik gereksinimler müşteri ihtiyaçlarının nasıl karşılanacağını göstermektedir. Kalite Fonksiyonu Göçerimi çalışmasının önemli kısımlarından birisidir. Çalışmanın yapıldığı kurumlara hizmet kalitesini arttırmak üzere neler yapilabileceği konusunda yardımcı olmaktadır.
Tablo 4'de Kalite Evi'nde yer alacak olan Planlama Matrisi gösterilmektedir. Bir hastanenin iyileştirilmesi için Nesnelerin İnterneti teknolojisi kapsamında gerekli olan gereksinimler ele alınarak Tablo 5'de belirtilmiştir. Belirtilen Teknik Gereksinimler Kalite Evi matrisine yerleştirilmiştir. Oluşturulan Kalite Evi Tablo 6'da bütün olarak verilmiştir.

Tablo 5. Müşteri İhtiyaçlarının Teknik Karakteristikleri

\begin{tabular}{|c|c|}
\hline Müşteri İhtiyaçları & Teknik Gereksinimler \\
\hline Fiziksel Boyut & $\begin{array}{l}\text {-Kablolu ve Kablosuz A ğ Altyapısının stabil ve yüksek erişilebilirlikte olması } \\
\text {-RFID Teknolojisinin sisteme entegresi } \\
\text {-RFID Okuyucularının yeterli sayıda olması } \\
\text {-Fiber altyapısı ile hastane içinde bant genişliğinin yüksek tutulması } \\
\text {-Kablosuz Erişim Noktaları sayısının arttırılması }\end{array}$ \\
\hline Güvenilirlik Boyutu & $\begin{array}{l}\text {-Raporlama sürecinin Bulut Biliş̧im üzerinden yapılması } \\
\text {-Hasta takip için giyilebilir teknolojilerin kullanılması } \\
\text {-Veri senkronizasyonunun anlık sağlanması } \\
\text {-QR-Kod uygulaması ile hızlı veri erişimi }\end{array}$ \\
\hline Heveslilik Boyutu & $\begin{array}{l}\text {-Hasta üzerindeki Kablosuz Vücut Algılayıcıları ile ilgili sağlık birimine } \\
\text { uyarı sistemi oluşturulması } \\
\text {-Sıra Takip uygulaması geliştirilmesi } \\
\text {-Otomatik Randevu Sistemi oluşturulması } \\
\text {-İnternet ve Mobil aracılığı ile randevu tanımlama } \\
\text {-Evde Bakım hizmetlerinin sunulması }\end{array}$ \\
\hline Güven Boyutu & $\begin{array}{l}\text {-Personelin teknik gelişmelere adaptesinin sürekli tutulması } \\
\text {-Parmak izi tanımlama ile kişiye özel şifreleme }\end{array}$ \\
\hline Empati Boyutu & $\begin{array}{l}\text {-Kişisel Verilerin Korunması ile ilgili hastaların bilgilendirilmesi } \\
\text {-Hastaların sağlık verilerinin gizlilik, güvenlik ve tutarlılığını sağlamak } \\
\text {-İnternet ve mobil uygulamalar üzerinden sağlık danışmanlığı }\end{array}$ \\
\hline
\end{tabular}




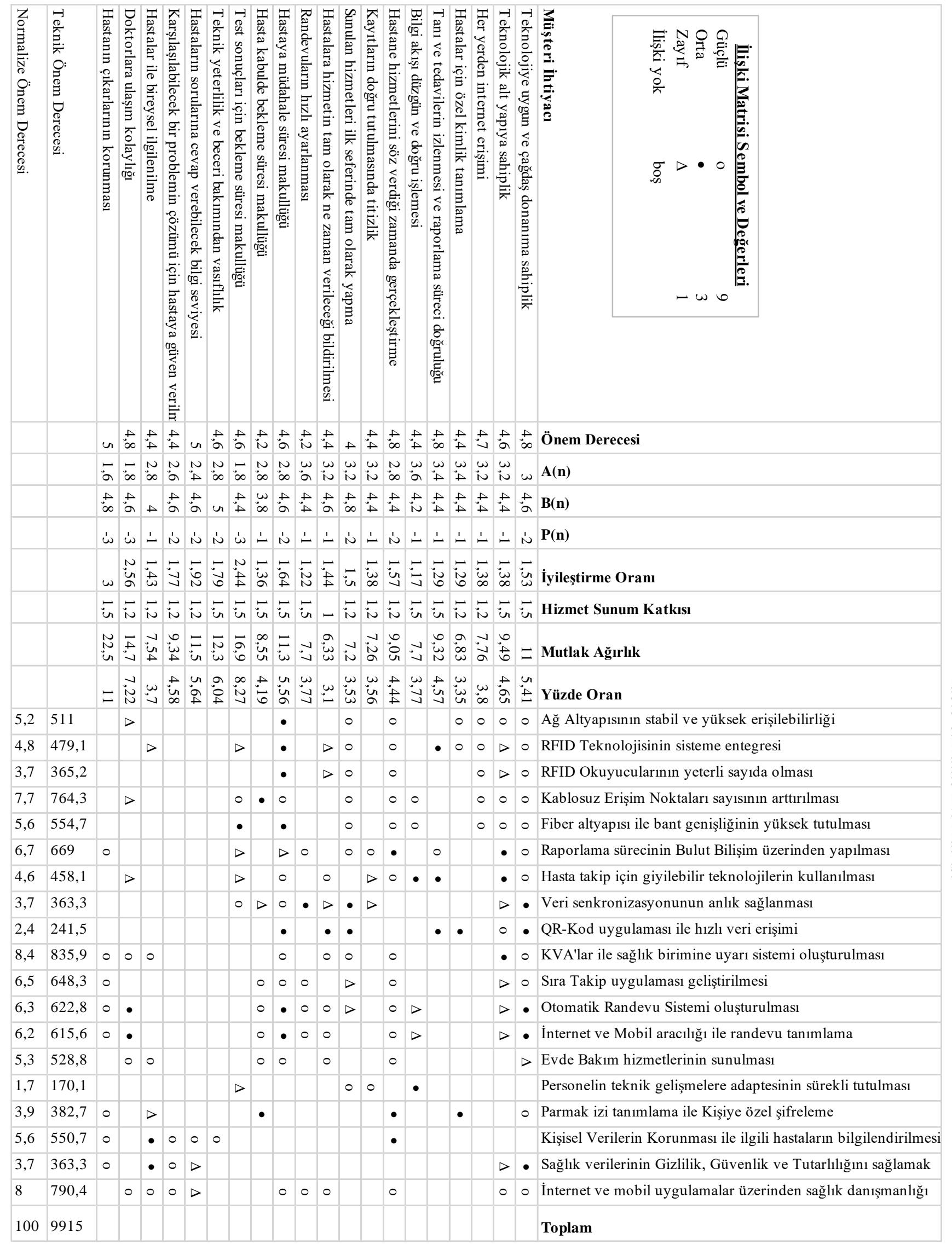


4-İlişki matrisinin oluşturulması: Müşteri İhtiyaçları ve teknik gereksinimler arasında bulunan ilişkilerin, ilişki kuvvetlerine göre değerlendirilerek ele alınması ile oluşturulmuştur. Yüksek düzeyde bir ilişki için "9" puan ve "o" sembolü, orta düzeyde bir ilişki bulunuyorsa " 3 " puan ve "•" sembolü, zayıf bir ilişki bulunuyorsa "1" puan ve " $\Delta$ " sembolü kullanılmıştır. Değerlendirmede kullanılan semboller yukarıda anlatıldığg ş̧ekilde çalışma yapılan matris üzerinde ele alınmıştır.

5-Teknik karakteristikler için mutlak ve bağıl önem derecelerinin hesaplanması: Hesaplamalar için gereken değerler planlama matrisinde hesaplanmış olan mutlak ağırlık ve satıra ilişkin ilişki düzeyi kullanılarak yapılır. Elde edilen değerler kalite evi matrisinde yerleştirilir.

Oluşturulan Kalite Evi Tablo 6'da incelendiğinde en yüksek teknik önem derecesine sahip olan teknik gereksinimin "Kablosuz Vücut Algılayıcıları ile sağlık birimlerine uyarı sistemi oluşturulması" olduğu görülmektedir. Daha sonra en yüksek teknik dereceye sahip teknik gereksinimin "İnternet ve mobil uygulamalar üzerinden sağlık danışmanlığ noktası sayısının arttırılması" olduğu görülmektedir.

İhtiyaçlar ve teknik gereksinimler karşılaştırıldığında en az teknik önem derecesine sahip teknik gereksinimin "Personelin teknik gelişmelere adaptasyonunun sürekli tutulması" olduğu ortaya çıkmaktadır. Bunun dışında teknik önem derecesi düşük olan bir diğer teknik gereksinimin "QR-Kod uygulaması ile sıra takibinde" olduğu görülmektedir.

\section{Sonuç}

Teknolojinin hayatımızı birçok alanda kolaylaştırdığı görülmektedir ve sağlık sektöründe teknolojiye adapte olma günümüzde bir zorunluluk haline gelmiştir. T1bbi bilgi teknolojileri sağlık çalışanları tarafından operasyon verimliliğini artırmak ve iş yüklerini azaltmak için kullanılmaktadır. Küresel olarak akıllı teknolojiler evlerimizde, ofislerimizde kısaca günlük hayatımızın her aşamada karşımıza çıkmaktadır. Akıllı teknolojilerin entegrasyonu, kullanım alanlarının artması ile birlikte giderek daha çok önem kazanmaktadır.

Dijital hastane, sağlık kurumu içerisindeki tüm bilgi sistemlerinin medikal ve medikal olmayan her türlü teknolojilerle tam entegre olduğu, güvenilir veri akışı standartlarının belirlendiği hastane olarak tanımlanır.. Dijital hastaneler hekim, hemşire vb. personele yetkileri çerçevesinde çok daha az zaman ve enerji harcayarak hastane ve hasta verilerine ve bilgilerine istenilen yerden istenilen zamanda erişimi sağlayan, sağlık görevlilerinin iş süreçlerini etkili kılmaktadır. Ayrıca doğru ilaç ve medikal tedavi uygulamalarının kontrol edildiği, gerçek anlamda bütün işlemlerin tam otomasyon sistemi ile yapıldığı, kontrol edildiği, yönetildiği bir hastane işleyişine ve ileri teknoloji donanımına sahiptir. Hastane çalışanlarına, hastalara ve yakınlarına etkili, verimli, ekonomik, erişilebilirliği yüksek ve kaliteli sağlık hizmeti sunmaya hedeflenmiş; üçüncü taraflar, esağlık ve e-devlet ile de tam entegre olan hastanelere "dijital hastane" denilmektedir (Hassanalieragh, ve diğerleri, 2015, s. 973).

Sağlık hizmetini gerçekleştirmek için uzaktan görüntüleme sistemlerine ihtiyaç duyulmaktadır. Gerçek zamanlı olarak uzaktan tıbbi uygulamaları hastaların fiziksel işaretlerini gönderebilecek yaygın bir izleme sistemi ile internet ve mobil e-ISSN: 2148-2683 uygulamalar üzerinden sağlık danışmanlığı imkânı sunulabilir. 2017 yılında yapılan bir çalışmada birden fazla fiziksel işaret (tansiyon, EKG, SpO2, kalp atış hızı, nabız, kan yağ ve kan şekeri) ve çevresel bir gösterge (hastaların bulunduğu yer) sürekli olarak farklı oranlarda örneklenecek şekilde sistem tasarlanmıştır. Hastaların riski, tıbbi analiz ihtiyaçları, iletişim talepleri ve bilgi işlem kaynakları dikkate alınarak dört veri iletim modu sunulmuştur ( Li, Hu, \& Zhang, 2017). Bu çalışma ile hedeflenen uzaktan sağlık hizmeti sağlanmıştır.

Akıllı nesne teknolojisindeki hızlı gelişme, kablosuz sensör tabanlı dağıtılmış iletişim mimarisi için uygulama geliştirmede önemli kazanımlar içermektedir. Ancak kazanımların yanında güvenlik tehditleri de getirdiği görülmektedir. Nesnelerin İnternet'indeki her akıllı nesne (veya sensör), sistem güvenlik açığı açısından potansiyel bir riski temsil eder. Başka bir deyişle, her akıllı nesne kötü amaçlı bir saldırı için savunmasız bir giriş noktası haline gelebilmektedir. Bu sebeple akıllı nesneler için fiziksel korumanın gerekliliği ve akıllı nesneler arasında veri toplama sırasında verilerin gizliliğinin, bütünlüğünün ve mahremiyetinin korunması önem arz etmektedir (YEH, 2016). 2016 yılında yapılan bir çalışmada ortak IoT tabanlı iletişim ağlarında sistem verimliliğini ve güçlü iletimi eşzamanlı olarak elde etmek için veri iletim gizliliğini sağlamak ve akıllı nesneler, yerel işlem birimi ve arka uç Kablosuz Vücut Algılayıcıları sunucusu arasında varlık kimlik doğrulaması sağlamak amacıyla iki iletişim mekanizması oluşturulurken güçlü şifreleme ilkeleri kullanılmıştır (YEH, 2016). Metinlerin tamamen korunmasız olarak transfer edilmesi yerine korumalı olarak karşı tarafa ulaşması için NSA tarafından geliştirilmiş metinlerin şifrelenerek özetlenebildiği ve daha sonradan tekrar çözümlenerek orijinal metin haline getirilebilir olan bir kriptografik özetleme fonksiyonu SHA (Secure Hash Algorithm) teknikleri kullanılmıştır.

\section{Kablosuz Vücut Algılayıcıları İle Sağlık Birimlerine Uyarı Sistemi Model Önerisi}

Kablosuz Vücut Algılayıcıları ile sağlık birimlerine uyarı sistemi oluşturulması için Giyilebilir Sensörler ve Kablosuz Vücut Algılayıcıları özellikle IoT teknolojisi ile donatılmış olanlar uzun süreli olarak verilerin gözlenmesi ve kaydedilmesi için cazip seçenekler sunmaktadır. Bu veriler analiz edildiğinde ve hekimlere asimilasyonu kolay görselleştirmede sunulduğunda, sağlık hizmetlerini iyileştirme ve maliyetleri azaltma potansiyeline sahiptir (Hassanalieragh, ve diğerleri, 2015). Akıllı nesne teknolojisindeki hızlı gelişme, kablosuz sensör tabanlı dağıtılmış iletişim mimarisi için uygulama geliştirmede önemli kazanımlar içermektedir.

Kablosuz Vücut Algılayıcıları ile sağlık birimlerine uyarı sistemi oluşturulması için gerekli sistemler şu şekilde siralanmaktadır;

Kablosuz İletişim Teknolojisi

Kablosuz Vücut Algılayıcıları

NB-IoT

\section{HBYS entegrasyonu}

Sistemlerin birbirleri ile doğru iletişim içerisinde olması için fiziksel konumlandırmaları ve iletişimlerinin sağlanması gerekmektedir. Şekil 5'de Kablosuz Vücut Algılayıcıları ile Hasta Takip ve Uyarı Sistemi şematik olarak gösterilmiştir. Kullanılacak olan Kablosuz Vücut Algılayıcıları HBYS sisteminde sunucuya eklenerek etiketlendirilir. Kablosuz Vücut Algılayıcıları ve NB- 
IoT cihazları ile eşleştirilir. Kablosuz Vücut Algılayıcılarından gelecek olan veriler NB-IoT teknolojisi ile GSM operatörleri altyapısı üzerinden veriler HBYS sistemine aktarılır ve daha önce belirlenen KVA etiketleri ile eşleştirilerek anlık veri alımı sağlanır. Şekil 6'da önerilen Kablosuz Vücut Algılayıcıları ile Hasta Takip ve Uyarı Sistemi'nin algoritma akış şeması verilmiştir. Anlık sağlanan veriler gerekli alarm durumu sınırları ile karşılaștırılarak devamlı olarak uzman sistem tarafından sorgulanır. Örneğin; Kablosuz Vücut Algılayıcısı tarafından gelen kan basıncı verisi, 19 yaşını geçmiş bir bireyde $140 \mathrm{~mm} \mathrm{Hg}$ ve üzerinde olması bir uyarı mekanizmasını çalıştırarak ilgili sağlık birimine verinin ve bu verinin kimden geldiği bilgilerinin paylaşılması sağlanır. Bu sayede ilgili personel ilgili kişi ile iletişime geçerek acil bir durum müdahalesinde bulunabilir.

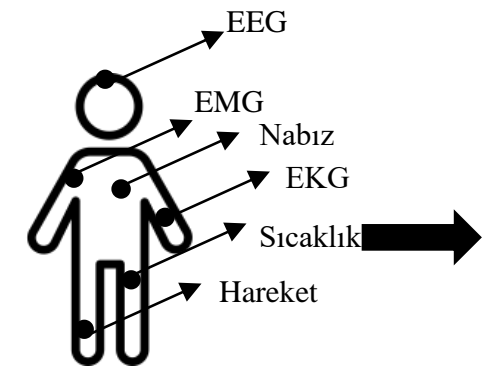

Sensörlerden Sicaklık, Nabız, Tansiyon, Solunum Hızı, GPS gibi veriler alınır

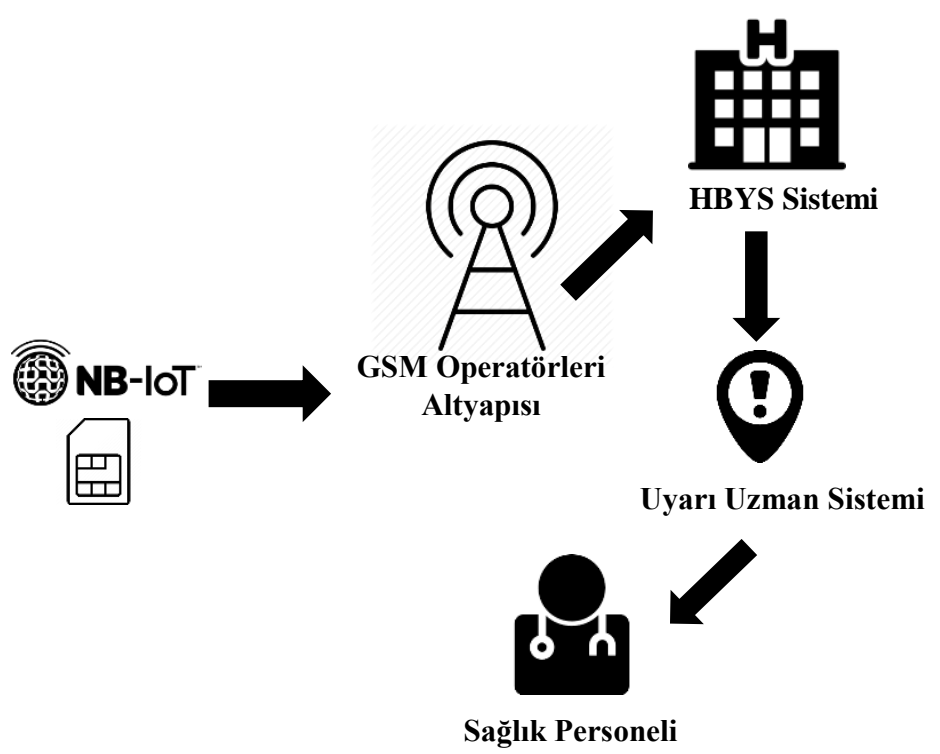

Sağlık Personeli

\section{Şekil 5. Kablosuz Vücut Algılayıcıları ile Hasta Takip ve Uyarı Sistemi Şeması}

Sağlık hizmetlerine erişimi zor olan evde yatan hastalar veya yaşlılar için uzaktan sistemler ile her yerde sağlık hizmetlerinin sunulması hastalıkların takibinin uzaktan yapılabilmesine imkân sağlamaktadır. Bu alanda başarılı sistem örneği olarak 2019 yılında yapılan bir çalışma gösterilebilir. Jabeen ve arkadaşları Sis bazlı bir IoT modeli, kardiyovasküler hastalığ bölgelerdeki hastalar için faydalı olabileceği görüşündedirler. Kalp hastalığını sınıflandırmak ve önerilerde bulunmak için mevcut bazı sistemler bulunmaktadır ancak bu mevcut sistemler sadece tavsiyeler için sınıflandırmayı kullanmaktadır. Jabeen ve arkadaşlarının yapmış oldukları çalışmada IoT tabanlı verimli bir topluluk tabanlı danışmanlık sistemi önermektedirler. Bu sistemin amacı kalp hastalığını ve tipini teşhis etmek, fiziksel duruma ve diyet planına göre önerilerde bulunmaktır. Sistemde ilk önce veriler biyosensörler kullanılarak hastadan uzaktan toplanır ve IoT tabanlı ortam sayesinde sunuculara iletilir. Önerilen sistem daha sonra veri işleme ve veri üzerinde özellik seçimi gerçekleştirir. Sistem için bir uzman kardiyoloğun yardımı ile iyi bilinen bir hastaneden hastalıklar ve bunlarla ilgili tavsiyeler için bir veri seti toplanır. Sistemin performansı hassasiyet, hatırlama ve ortalama mutlak hata açısından değerlendirilmiş ve sonuçta \% 98 doğruluk sağlanmıştır. Sistem, uzman bir kardiyoloğun genellikle bulunamadığı uzak bölgelerdeki hastalar için iyi bir performans ortaya koymaktadır. Bu önerilen çalışma, daha genç ve yeni bir kardiyoloğa hızlı bir tıbbi karar vermede yardımc1 olabilecektir (Jabeen, ve diğerleri, 2019). 


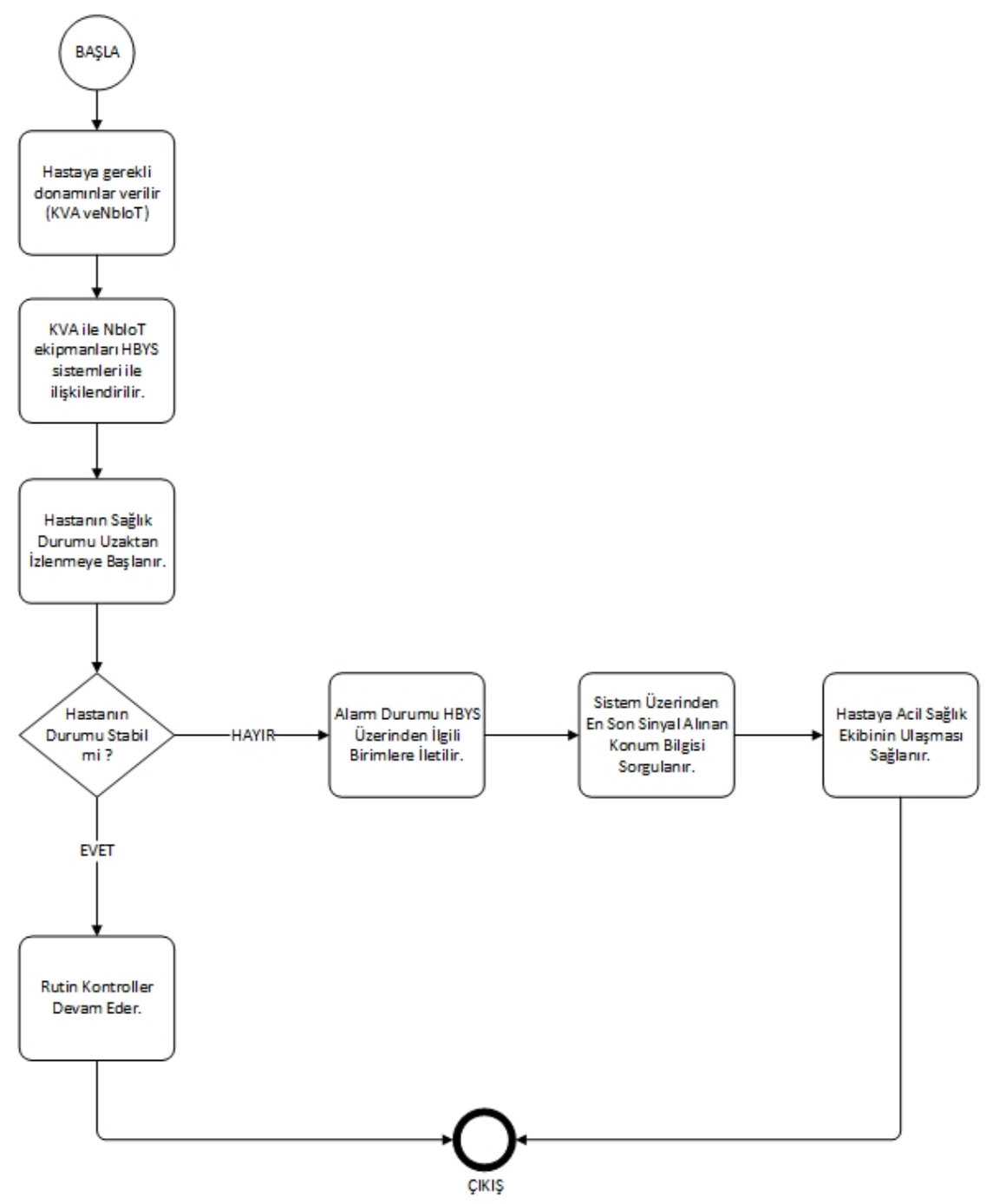

Şekil 6. Kablosuz Vücut Algllayıcıları İle Hasta Takip ve Uyarı Sistemi Algoritma Şeması

Bahsedilen makalelerde kullanılan sistemlerden faydalanılarak bir model oluşturulmuştur. Model incelendiğinde Kalite Fonksiyonu Göçerimi yöntemi ile ortaya çıkan "Kablosuz Vücut Algılayıcıları İle Sağlık Birimlerine Uyarı Sistemi" ihtiyacının karşılanabildiği görülmektedir. Bu model sayesinde hastane hizmetleri daha verimli bir hale getirilerek dijital hastane anlayışına daha da yaklaşılmış olunmaktadır.

\section{Kaynakça}

Li, C., Hu, X., \& Zhang, L. (2017). The IoT-based heart disease monitoring system for pervasive healthcare service. International Conference on Knowledge Based and Intelligent Information and Engineering Systems (s. 23282334). Marseille, France : Procedia Computer Science .

Akbaba, A. (2005, 2). Yeni ürün geliştirme sürecinde kalite fonksiyon göçerimi (KFG): Turizm işletmeleri için KFG temelli bir ürün geliştirme süreci önerisi. Karamanoğlu Mehmetbey Üniversitesi Sosyal ve Ekonomik Araştırmalar Dergisi, s. 38-59.

Aktaş, F., Çeken, C., \& Erdemli, Y. E. (2014). Biyomedikal Uygulamaları için Nesnelerin İnterneti Tabanlı Veri Toplama ve Veri Analiz Sistemi. Tip Teknolojileri Ulusal Kongresi, (s. 299-302). Kapadokya.
Aktaş, F., Çeken, C., \& Erdemli, Y. E. (2016, 4). Nesnelerin Interneti Teknolojisinin Biyomedikal Alanındaki Uygulamalar1. Düzce Üniversitesi Bilim ve Teknoloji Dergisi, s. 37-54.

Aktepe, A., Ersöz, S., Hayat, Y., Orhan, G., Can, C., \& Çİftci, S. (2011). Kalite Fonksiyonu Yayılımı (KFY)'de SERVQUAL Analizi ve Bulanık Analitik Hiyerarşi Prosesi (BHP) Yöntemlerinin Bütünleşik Kullanımı: Bir Üniversite Hastanesinde Uygulama. XI. Üretim Araştırmalar Sempozyumu (s. 237-246). İstanbul: İstanbul Ticaret Üniversitesi.

Al Memari, A. S. (2016). Improving Healthcare Services by Quality Function Deployment (QFD). Dubai: The British University in Dubai.

Camgöz-Akdağ, H., Tarım, M., Lonial, S., \& Yatkın, A. (2013, Şubat 8). QFD application using SERVQUAL for private hospitals:A Case Study. Leadership in Health Services, 26(3), s. $175-183$

Chiuchisan, I., Costin, H.-N., \& Geman, O. (2014). Adopting the Internet of Things Technologies in Health Care Systems. International Conference and Exposition on Electrical and Power Engineering, (s. 532-535). Iasi, Romania.

Değer, Ç. (2012). Kano Modeli İle Bütünleştirilmiş Servqual Analizinin Kalite Fonksiyon Yayılımına Uygulanarak Hizmet Kalitesinin İyileştirilmesi Ve Bir Sağlık Kuruluşunda Uygulanması(Yüksek Lisans Tezi). İzmir: Dokuz Eylül 
Üniversitesi Sosyal Bilimler Enstitüsü İsletme Anabilim Dall Hastane Ve Sağllk Kuruluşları Yönetimi .

Devebakan, N., \& Aksaraylı, M. (2003, 5 1). Sağlık İşletmelerinde Algılanan Hizmet Kalitesinin Ölçümünde SERVQUAL Skorlarının Kullanımı ve Özel Altınordu Hastanesi Uygulaması. Dokuz Eylül Üniversitesi Sosyal Bilimler Enstitüsü Dergisi, s. 38-54.

Grönroos, C. (1983, 18 4). A Service Quality Model and Its Marketing Implications. European Journal of Marketting, s. 36-44.

Güllü, E., \& Ulcay, Y. (2002, 7 1). Kalite Fonksiyonu Yayılımı ve Bir Uygulama. Uludağ Üniversitesi Mühendislik-Mimarlık Fakültesi Dergisi, s. 71-91.

Hassanalieragh, M., Page, A., Soyata, T., Sharma, G., Aktas, M., Mateos, G., ... Andreescu, S. (2015). Health Monitoring and Management Using Internet-of-Things (IoT) Sensing with Cloud-based Processing: Opportunities and Challenges. IEEE International Conference on Services Computing, (s. 285-292). New York City, NY, USA.

Huawei Technology Cooperation. (2015). NB-IOT-Enabling New Business Opportunities. Huawei White Paper, 4-23.

Işık, O., Seğmen, Y. E., \& Kölemen, M. (2012, Ocak). Kalite Fonksiyon Yayılımı (KFY) Kullanarak Mühendislik Programı Tasarımı. Havacilık ve Uzay Teknolojileri Dergisi, s. 55-60.

Jabeen, F., Maqsood, M., Ghazanfar, M. A., Aadil, F., Khan, S., Khan, M. F., \& Mehmood, I. (2019, February 17). An IoT Based Efficient Hybrid Recommender System For Cardiovascular Disease. Peer-to-Peer Networking and Applications, s. 1-14.

Karahan, K. (2000). Hizmet Pazarlaması. İstanbul: Beta Yayın Dağıtım A. Ş.

Kılınç, T. (2007). Rfid Sistemlerin Incelenmesi ve Sağllk Sektöründe Kullanılması (Yüksek Lisans Tezi). İstanbul: Maltepe Üniversitesi Fen Bilimleri Enstitüsü Bilgisayar Mühendisliği Anabilim Dalı .

Lee, B., \& Ouyang, J. (2014, Vol.6 No.1). Intelligent Healthcare Service by using Collaborations between IoT Personal Health Devices. International Journal of Bio-Science and BioTechnology, s. 155-164.

Ökdem, S., \& Karaboğa, D. (2007). Kablosuz Algılayıcı Ağlarında Yönlendirme Teknikleri. IX. Akademik Bilişim Konferansı Bildirileri (s. 409-415). Kütahya: Dumlupınar Üniversitesi.

Özdemir, A., Naralan Nursaçan, M. N., \& Nursaçan, İ. C. (2018, Kasım). 2014-2018 Yılları Arasında Nesnelerin İnterneti (Iot) Üzerine Bir. Bandırma Onyedi Eylül Üniversitesi Sosyal Bilimler Araştırmaları Dergisi, s. 1-22.

Parasuraman, A., Zeithaml, V. A., \& Berry, L. L. (1985, 49). A Conceptual Model of Service Quality and Its Implications for Future Research. Journal of Marketing, s. 41-50.

Rahman, S., Erdem, R., \& Devebakan, N. (2007, 9 3). Hizmet Kalitesinin Servqual Ölçeği ile Değerlendirilmesi: Elazığ'daki Hastaneler Üzerinde Bir Çalışma . Dokuz Eylül Üniversitesi Sosyal Bilimler Enstitüsü Dergisi , s. 37-55.

Savaş, H., \& Kesmez, A. G. (2014, 17). Hizmet Kalitesinin Servqual Modeli ile Ölçülmesi: Aile Sağllğı Merkezleri Üzerine Bir Araştırma. Pamukkale Üniversitesi Sosyal Bilimler Enstitüsü Dergisi, s. 1-13.

Sönmez Çakır, F., Aytekin, A., \& Tümçin, F. (2018, Cilt:4 Sayı:5). Nesnelerin İnterneti Ve Giyilebilir Teknolojiler. Sosyal Araştırmalar ve Davranış Bilimleri Dergisi, s. 84-95.
Türker, G. F., \& Tarımer, İ. (2011). Türkiye'de Kablosuz Algılayıcı Ağlar ile Yapılan Teknolojik Uygulamalar Üzerine Bir İnceleme. XIII. Akademik Biliş̧im Konferansı Bildirileri (s. 75-81). Malatya: İnönü Üniversitesi.

Want, R. (2006, 5 1). An Introduction to RFID Technology. IEEE Pervasive Computing, s. 25-33.

Xu, B., Xu, L., Cai, H., Xie, C., Hu, J., \& Bu, F. (2014, Mayıs). Ubiquitous Data Accessing Method in IoT-Based Information System for Emergency Medical Services. IEEE Transactoons On Industrial Informatics, s. 1578-1586.

Yeh, K.-H. (2016, 4). A Secure IoT-Based Healthcare System With Body Sensor Networks. IEEE Access, s. 10288-10299. 